\title{
THE IMPACT OF E-GOVERNMENT ON ECONOMIC GROWTH IN GCC COUNTRIES
}

\author{
AL-REFAI Mohammed S. ${ }^{1}$ \\ ${ }^{1}$ Northern Border University, Arar (SAUDI ARABIA) \\ Email: mohammedrefai2017@gmail.com
}

\begin{abstract}
This study is the first to empirically examine the impact of e-government on economic growth in Gulf Cooperation Council countries. The dataset used in the study covers the period 2003-2018 and is obtained from the World Development Indicators and the United Nations EGovernment knowledgebase. The conducted empirical analysis brings out many interesting findings. First, there is evidence that the e-government development stimulated economic growth in GCC during the last two decades. Second, when considering the different components of e-government, it has been shown that only the Online Service Index and the Telecommunication Infrastructure Index have positive effects on economic growth. Finally, it has been also revealed that out from six countries, the positive impact of e-government is proved in only four countries, namely Bahrain, Kuwait, Saudi Arabia and the United Arab Emirates. In Oman and Qatar, the effect is not statistically significant. Global and countryspecific policy recommendations are accordingly presented.
\end{abstract}

Keywords: e-government, e-government development index, economic growth, gulf cooperation council

JEL: $H 11$

UDC: $35.077: 004$ 330.341.2

COBISS.SR-ID: 18169865

\section{Introduction and Background}

During the last decades, significant achievements regarding technological progress have been reached. Although some disparities between developing and developed countries regarding the adoption of new technologies have been observed, a common trend toward increased use of these technologies has been recorded. It has been often advanced that the adoption of new technologies is of great importance since it facilitates the access to services for citizens, supports economic growth, and improves the well-being of nations. The adoption of new technologies has touched almost all economic sectors, such as industry, agriculture, and transportation.

One of the crucial features of the emergence of new technologies in modern societies is undoubtedly the adoption of electronic government (e-government). Indeed, the concept of egovernment came out in the mid-nineties of the last century [1] and has been developed first in developed countries and then in developing ones. Since then, many definitions of egovernment have been proposed. For example, the U.S. E-Government Act of 2002 defines egovernment as "the use by the Government of web-based Internet applications and other information technologies, combined with processes that implement these technologies" [2].

The World Bank (2002) defines e-government as "the use by government agencies of information technology tools, such as Wide Area Networks (WANs), the Internet, and mobile computing, that have the ability to transform relations with citizens, businesses, and other 
arms of government" [3] (World Bank, 2002, p. 2). Finally, the OECD [4] (defines egovernment as "the use of ICTs, and particularly the Internet, as a tool to achieve better government" [4]. Although a significant number of definitions have emerged in the literature, there is no consensus on a precise definition of e-government [5].

Thanks to its advantages, e-government policies have been overgrowing during the last three decades. According to the United Nations E-Government Survey 2018, the average EGovernment Development Index (EGDI) rises from 0.47 in 2014 to 0.55 in 2018. Moreover, 40 countries obtained a "very-high" EGDI score ranging between 0.75 and 1.00 in 2018, while there have been only 10 countries in 2003. The development of e-government and the availability of needed datasets have incited scholars to focus on many topics linked to egovernment. Some of them studied the determinants of e-government implementation [6], [7], while others dealt with barriers and challenges to the expansion of e-government [8], [9] and finally the economic and societal effects of e-government [10], [11], [12].

This paper aims to study the effect of e-government on economic development in six Gulf Cooperation Council countries between 2003 and 2018. It is motivated by the fact that these countries have implemented e-government services since many years ago and also driven by the lack of empirical researches focusing on the response of economic growth to egovernment development. For example, Saudi Arabia jumped from the 105th rank in 2003 to the $44^{\text {th }}$ out of 193 nations included in the 2018 United Nations E-Government Survey.

During the same year, good results have also been achieved by the United Arab Emirates $\left(21^{\text {st }}\right)$ and Bahrain $\left(26^{\text {th }}\right)$. The study conducts an empirical exploration using data obtained from the World Development Indicators produced by the World Bank and the UN EGovernment Knowledgebase produced by the United Nations Department of Economic and Social Affairs (Division for Public Institutions and Digital Government).

The remainder of this paper is organized as follows. In Section 2, we review the related literature. Section 3 is dedicated to the presentation of model and data, while in Section 4, we interpret empirical results. The conclusion is developed in Section 5.

\section{Literature Survey}

While the literature on the economic outcomes of e-government is relatively recent, the economic theory has attributed an essential role to the technological progress as a determinant of economic development. Indeed, e-government may affect economic development through many channels. First, the set up and development of e-government may reduce the time to generate and deliver services to citizens [13]. As a result, e-government may reduce the cost of public services and administrative burdens. According to Gustova [14], the cost reduction induced by the use of e-government is due to three main reasons, namely savings in labor costs, savings in service delivery, and savings in electronic invoicing. Second, Thanh and Kim [15] point out that the e-government strategy makes the efficiency and effectiveness of public services better. Regarding this point, Von Haldenwang [16] states that e-government allows more internal and production efficiency of the public sector. By doing so, egovernment may lead to less bureaucracy in public services [17], [18]. Third, e-government may reduce corruption and improve transparency in the public sector and then encourage business [19], [20]. This is done through the possibility of accessing to the public information by citizens [14]. The reduction of corruption will exert a positive effect on the economic progress, as stated by many authors, such as Ahmad et al., [21] and Hassan [22].

Srivastava and Panigrahi [12] conducted an empirical analysis on the outcomes of egovernment and e-business on per capita gross domestic product in a sample composed of 145 countries. The authors show that e-business exerts a positive impact in developed countries, while e-government positively affects growth in developing countries. Majeed and Malik [11] 
analyzed the linkages between financial development, growth and e-government in 147 economies and concluded that e-government significantly boosts economic growth.

Moreover, e-government is an essential prerequisite for the success of financial development in boosting economic progress. Chaushi et al., [23] studied the reaction of economic growth to e-government in a large number of countries between 2003 and 2014.

The growth model has been estimated using the fixed effects model, Hausman-Taylor technique and the difference Generalized Method of Moments technique. Results show the presence of positive outcomes of e-government on economic development.

Gustova [14] studies the effects of e-government on GDP in 34 European countries. The author showed that e-government had been associated with higher economic growth between 2003 and 2014. Hassan [22] studied the linkage between corruption, e-government, the environment, and economic growth in 11 Asian economies between 2003 and 2013. The most important finding of the study is that e-government participated in boosting economic growth and fighting corruption in the studied countries. These results have been confirmed by those of Majeed and Shah [20] who explore the outcome of e-government on economic progress in 34 Asian countries. Using a wide range of estimation techniques, the authors confirm the importance of e-government in stimulating growth in the studied countries. Bahrini and Qaffas [24] examine the effects of Information and Communication Technology (ICT) on development growth in a sample composed of the Middle East and North Africa (MENA) countries and Sub-Saharan Africa (SSA) countries. Various indicators of ICT adoption have been used, such as broadband adoption, internet usage and mobile phones. Results show that all indicators, except fixed telephone, positively affect economic development. Besides, the effect is smaller in Sub-Saharan African countries than MENA countries.

\section{Research Methodology and Data}

\section{Research Methodology}

The paper aims are to analyze the impact of e-government on economic growth in 6 Gulf Cooperation Council countries, namely the United Arab Emirates, Kuwait, Qatar, Saudi Arabia, Oman and Bahrain during the period 2003-2018. The following model will be estimated:

$$
G D P P C_{=} \omega+\alpha E G O V+\beta X+\varepsilon(1)
$$

$G D P P C$ is the per capita gross domestic product, $\omega$ is a constant, $E G O V$ is the egovernment indicator, $X$ represents control variables (labor ' $L$ ' and capital ' $K$ '). The research methodology of the paper is summarized in Figure 1.

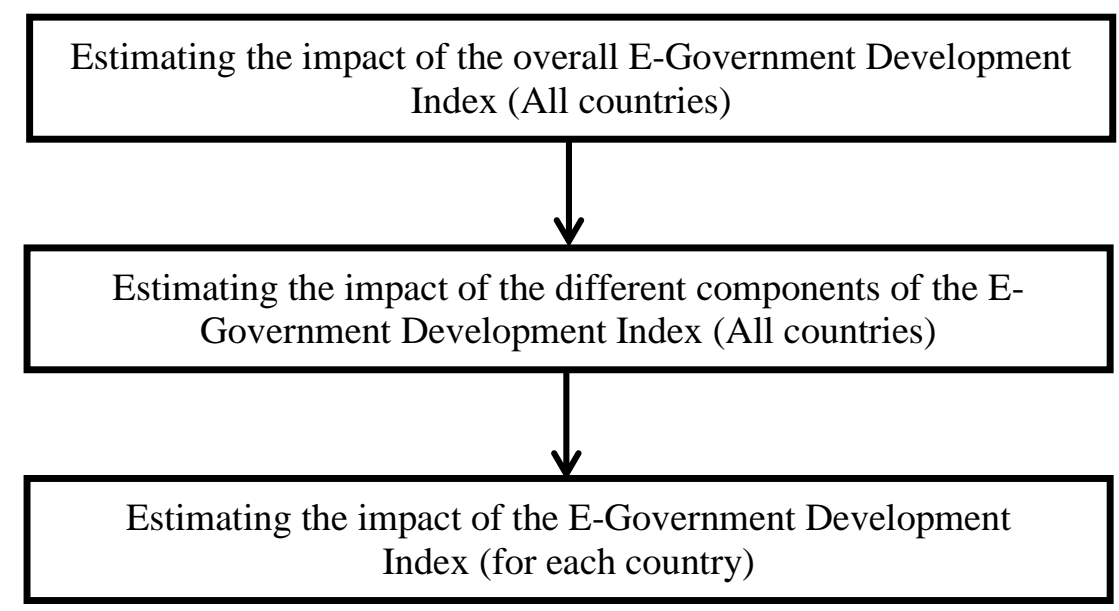

Fig. 1. The research methodology 


\section{Data}

Two sources of data are employed. First, the e-government indicators are from the UN EGovernment Knowledgebase produced by the Division for Public Institutions and Digital Government of the United Nations Department of Economic and Social Affairs.

Table 1. Definition of e-government indicators

\begin{tabular}{|c|c|c|}
\hline Abbreviation & Indicator & Construction \\
\hline EGDI & E-Government Development Index & EGDI = 1/3 (OSI+HCI+TTI) \\
\hline \multirow{5}{*}{ TII } & \multirow{5}{*}{$\begin{array}{l}\text { Telecommunication Infrastructure } \\
\text { Index }\end{array}$} & 1.Internet users per 100 inhabitants \\
\hline & & 2. Number of main fixed telephone lines per 100 \\
\hline & & 3. Number of mobile subscribers per 100 inhabitants \\
\hline & & $\begin{array}{l}\text { 4. Number of wireless broadband subscriptions per } 100 \\
\text { inhabitants }\end{array}$ \\
\hline & & $\begin{array}{l}\text { 5. Number of fixed broadband subscriptions per } 100 \\
\text { inhabitants }\end{array}$ \\
\hline \multirow{4}{*}{ HCI } & \multirow{4}{*}{ Human Capital Index } & 1. Adult literacy rate \\
\hline & & 2. Tertiary, secondary and primary gross enrolment \\
\hline & & 3. Expected years of schooling \\
\hline & & 4. Average years of schooling \\
\hline OSI & Online Service Index & Scope and quality of online services \\
\hline
\end{tabular}

Source: [26]

The dataset contains a global e-government indicator (E-Government Development Index, EGDI). It is the average of the three indices, namely the Telecommunication Infrastructure Index (TII), the Online Service Index (OSI), and the Human Capital Index (HCI). Table 1 below gives an idea on the constriction of the e-government indicators. The second source of data is the World Development Indicators of the World Bank. From this dataset, we obtained the per capita GDP, investment, and employment. A big progress in the implementation and development of e-government in almost all GCC countries has been recorded during the period 2003-2018. Scores obtained by all countries are very high since they ranged between 0.8 and 1 (the maximum) in 2018. The United Arab Emirates have the highest score for the global E-Government Development Index (0.829), the Telecommunication Infrastructure Index (0.856) and the Online Services Index (0.944) in 2018, while Saudi Arabia obtained the highest Human Capital Index (0.81) during the same year. In Table 2, some descriptive statistics of variables are presented. The average EGDI during the whole period is relatively low (0.58598) with a maximum of 0.82950. The EGDI was low in the 2000s and started to grow to reach high levels in 2018. The OSI has the highest score with 0.9444 recorded in the United Arab Emirates in 2018.

Table 2. Descriptive statistics

\begin{tabular}{|c|c|c|c|c||}
\hline & Mean & Maximum & Minimum & Std. Dev. \\
\hline$G D P P C$ & 10.3380 & 11.1516 & 9.65911 & 0.48989 \\
\hline$E G D I$ & 0.58598 & 0.82950 & 0.28841 & 0.12613 \\
\hline$O S I$ & 0.55729 & 0.94440 & 0.05019 & 0.22737 \\
\hline$T I I$ & 0.43279 & 0.85640 & 0.11928 & 0.18782 \\
\hline$H C I$ & 0.76859 & 0.89326 & 0.66240 & 0.06440 \\
\hline$K$ & 24.1692 & 26.0909 & 21.8228 & 1.15683 \\
\hline$L$ & 14.4330 & 16.3604 & 12.6645 & 1.01595 \\
\hline
\end{tabular}

Note: GDPPC, $K$ and L are taken in natural logarithm 


\section{Regression Results}

\section{The Impact of the E-Government Development Index (All Countries)}

Table 3 reports the effects of the E-Government Development Index on gross domestic product. Results show that the coefficient is positive and significant at the $99 \%$ likelihood, which means that the coefficient is highly significant.

Table 3. The effects of the E-Government Development Index (All countries)

\begin{tabular}{|c|c|c|c|}
\hline & Coefficient & Std. Error & Sig. \\
\hline Constant & $11.50590^{* * *}$ & 0.775272 & 0.000 \\
\hline E-Government Development Index & $0.457584 * * *$ & 0.164884 & 0.007 \\
\hline Investment & $0.160081 * * *$ & 0.044351 & 0.001 \\
\hline Employment & $-0.369167 * * *$ & 0.056965 & 0.000 \\
\hline R-squared & \multicolumn{3}{|c}{0.3870} \\
\hline
\end{tabular}

Note: * significance with $90 \%$ likelihood; ** significance with 95\% likelihood; **** significance with $99 \%$ likelihood

Consequently, we conclude that there is a positive connection between e-government and economic growth in GCC countries as a whole between 2003 and 2018. These results are expected since GCC countries made significant efforts during the last two decades to develop their e-government infrastructure. This is materialized by the improvement of their rankings according to the United Nations E-Government Survey 2018. These findings are in line with those of Majeed and Malik [11], Chaushi et al., [23], and Gustova [14] who report the importance of e-government in boosting economic growth.

Moreover, our results corroborate those of Hodrab [25] who concludes that economic growth in some Arab countries. Table 3 also indicates that investment has a positive effect economic development in GCC, while employment represents an obstacle to the improvement of growth. Coefficients are significant at $1 \%$ level. Finally, the R-squared is about 0.39, meaning that the selected variables explain $39 \%$ of economic growth in GCC countries, which is relatively acceptable.

\section{The Impact of Components of the E-Government Development Index (All Countries)}

While the overall impact of the E-Government Development Index on economic growth is positive, nothing can be said about the impact of the different components of the global index.

The purpose of this section is to estimate the impact of the three components of the EGovernment Development Index, namely the Online Service Index, the Telecommunication Infrastructure Index, and the Human Capital Index. Results are summarized in Table 4.

Results show that coefficients of the Online Service Index and the Telecommunication Infrastructure Index are positive and statistically significant in the group of GCC. While the coefficient of the Online Service Index is highly significant (1\%), the coefficient of the Telecommunication Infrastructure Index is less significant (10\%). Besides, the coefficient of the Online Service Index (0.248103) is more significant than the coefficient of the Telecommunication Infrastructure Index (0.179525).

Table 4. The effect of components of the E-Government Development Index (All countries)

\begin{tabular}{|c|c|c|c|}
\hline & Coefficient & Std. Error & Sig. \\
\hline \hline Constant & $11.64791^{* * *}$ & 0.72076 & 0.000 \\
\hline Online Service Index & $0.248103 * * *$ & 0.072861 & 0.001 \\
\hline Investment & $0.160307 * * *$ & 0.042771 & 0.001 \\
\hline Employment & $-0.370519 * * *$ & 0.05396 & 0.000 \\
\hline R-squared & \multicolumn{3}{|c}{0.4166} \\
\hline
\end{tabular}




\begin{tabular}{|c|c|c|c|}
\hline & Coefficient & Std. Error & Sig. \\
\hline Constant & $10.68732 * * *$ & 0.683629 & 0.000 \\
\hline Telecommunication Infrastructure Index & $0.179525^{*}$ & 0.098287 & 0.072 \\
\hline Investment & $0.190120 * * *$ & 0.044005 & 0.000 \\
\hline Employment & $-0.349536 * * *$ & 0.059566 & 0.000 \\
\hline \multirow[t]{2}{*}{ R-squared } & \multicolumn{3}{|c|}{0.3500} \\
\hline & Coefficient & Std. Error & Sig. \\
\hline Constant & $10.33433 * * *$ & 0.550132 & 0.000 \\
\hline Human Capital Index & $-0.506271 * * *$ & 0.188657 & 0.009 \\
\hline Investment & $0.22767 * * *$ & 0.044708 & 0.000 \\
\hline Employment & $-0.355720 * * *$ & 0.055364 & 0.000 \\
\hline R-squared & \multicolumn{3}{|c|}{0.3830} \\
\hline
\end{tabular}

Note: * significance with $90 \%$ likelihood; ** significance with 95\% likelihood; *** significance with $99 \%$

Consequently, we conclude that there is a positive connection between e-government and economic growth in GCC countries as a whole between 2003 and 2018. These results are expected since GCC countries made significant efforts during the last two decades to develop their e-government infrastructure. This is materialized by the improvement of their rankings according to the United Nations E-Government Survey 2018. These findings are in line with those of Majeed and Malik [11], Chaushi et al., [23] and Gustova [14] who report the importance of e-government in boosting economic growth. Moreover, our results corroborate those of Hodrab (2016) who concludes that economic growth in some Arab countries. Table 3 also indicates that investment has a positive effect economic development in GCC, while employment represents an obstacle to the improvement of growth. Coefficients are significant at $1 \%$ level. Finally, the R-squared is about 0.39 , meaning that the selected variables explain $39 \%$ of economic growth in GCC countries, which is relatively acceptable.

\section{The Impact of the E-Government Development Index (For Each Country)}

We now estimate the impact of the E-Government Development Index for each country.

Table 5 summarizes the regression results. As shown, the coefficient of the E-Government Development Index is positive and statistically significant in four countries: Bahrain, Kuwait, the United Arab Emirates and Saudi Arabia. Coefficients are significant at 1\% in Bahrain, the United Arab Emirates and Saudi Arabia, while it is significant at $10 \%$ in Kuwait. These findings reveal that the adoption and development of e-government services in these 4 Gulf Cooperation Council countries positively affected economic growth starting from 2003. The highest coefficient is found in United Arab Emirates (0.97567) and Saudi Arabia (0.67860).

Table 5. The effects of the E-Government Development Index (Each country)

\begin{tabular}{|c|c|c|c|}
\hline & Coefficient & Std. Error & Sig. \\
\hline \multicolumn{4}{|l|}{ Bahrain } \\
\hline Constant & $11.49022 * * *$ & 0.54867 & 0.0000 \\
\hline E-Government Development Index & $0.60402 * * *$ & 0.13830 & 0.0011 \\
\hline Investment & $0.14899 * * *$ & 0.03789 & 0.0023 \\
\hline Employment & $-0.39872 * * *$ & 0.08089 & 0.0005 \\
\hline R-squared & \multicolumn{3}{|c|}{0.6184} \\
\hline \multicolumn{4}{|l|}{ Kuwait } \\
\hline Constant & $24.05320 * * *$ & 1.98356 & 0.0003 \\
\hline E-Government Development Index & $0.67728^{*}$ & 0.26230 & 0.0612 \\
\hline Investment & $-0.57825 * * *$ & 0.06798 & 0.0010 \\
\hline Employment & -0.00848 & 0.08375 & 0.9242 \\
\hline R-squared & \multicolumn{3}{|c|}{0.9749} \\
\hline
\end{tabular}




\begin{tabular}{|c|c|c|c|}
\hline \multicolumn{4}{|l|}{ "Oman } \\
\hline Constant & $10.94771 * * *$ & 1.16478 & 0.0000 \\
\hline E-Government Development Index & 0.21947 & 0.29006 & 0.4652 \\
\hline Investment & $0.07375 * *$ & 0.03246 & 0.0442 \\
\hline Employment & $-0.21426 * * *$ & 0.06705 & 0.0085 \\
\hline R-squared & \multicolumn{3}{|c|}{0.6594} \\
\hline \multicolumn{4}{|l|}{ Saudi Arabia } \\
\hline Constant & $12.17422 * * *$ & 1.62593 & 0.0000 \\
\hline E-Government Development Index & $0.67860 * * *$ & 0.19709 & 0.0049 \\
\hline Investment & -0.00921 & 0.02505 & 0.7195 \\
\hline Employment & -0.15066 & 0.09246 & 0.1292 \\
\hline R-squared & \multicolumn{3}{|c|}{0.8966} \\
\hline \multicolumn{4}{|l|}{ Qatar } \\
\hline Constant & $10.02984 * * *$ & 0.50107 & 0.0000 \\
\hline E-Government Development Index & -0.32576 & 0.19406 & 0.1214 \\
\hline Investment & 0.01876 & 0.03900 & 0.6399 \\
\hline Employment & 0.05671 & 0.05445 & 0.3200 \\
\hline R-squared & \multicolumn{3}{|c|}{0.3214} \\
\hline \multicolumn{4}{|l|}{ United Arab Emirates } \\
\hline Constant & $17.01272 * * *$ & 1.69608 & 0.0000 \\
\hline E-Government Development Index & $0.97567 * * *$ & 0.22036 & 0.0010 \\
\hline Investment & 0.17968 & 0.10225 & 0.1066 \\
\hline Employment & $-0.75149 * * *$ & 0.07939 & 0.0000 \\
\hline
\end{tabular}

Note: * significance with $90 \%$ likelihood; ** significance with95 \% likelihood; *** significance with $99 \%$

These findings are expected since the four countries recorded good ranks in the United Nations E-Government Survey 2018: 21 for United Arab Emirates, 26 for Bahrain, 41 for Kuwait and 52 for Saudi Arabia. R-squared are also relatively high (ranging from 0.6184 in Bahrain to 0.9749 in Kuwait) and show that the independent variables well explain economic growth in GCC. Regarding Oman and Qatar, the regression results show that the coefficients are not statistically significant since p-values are higher than $10 \%(0.4652$ for Oman and 0.1214 for Qatar). These results suggest the adoption of e-government policies did not exert effects on economic development in these two countries during the last two decades. Indeed, Oman and Qatar recorded the lowest E-Government Development Index during previous decades. It seems that more efforts should be made in these two countries in terms of egovernment implementation and development so that it will enhance economic growth in the future. R-squared is relatively low in these two countries (compared to other countries), especially in Qatar (0.3214), meaning that there are other variables that explain better economic growth.

\section{Conclusions}

During the last decades, GCC countries have adopted many structural reforms to support economic development and enhance well-being. One of the reforms that have been paid considerable attention since the 1990s is the implementation of e-government services. This study aims to examine the outcomes of e-government on economic development in six GCC countries. To the best of our knowledge, it is the first and only research that conducts an empirical examination of the economic effects of e-government in GCC countries. The study is based on data covering the period 2003-2018 and extracted from the World Development Indicators (World Bank) and the UN E-Government Knowledgebase (United Nations). Our empirical strategy consists of estimating: i) the impact of the global E-Government 
Development Index on economic growth in the overall sample; ii) the impact of the EGovernment Development Index components (Online Service Index, Telecommunication Infrastructure Index, and Human Capital Index) on economic growth, and iii) the impact of the global E-Government Development Index on economic development in each country.

The empirical study shows interesting results. First, it has been found that the EGovernment Development Index positively affects economic growth in the overall sample. In other words, efforts made to implement e-government services in GCC countries have stimulated economic progress in those nations during the last two decades. Second, when considering the three sub-indices of the E-Government Development Index in the full sample of countries, results show that the Telecommunication Infrastructure Index and Online Service Index have positive effects on economic growth, while the effect of the Human Capital Index is negative and significant. It has also been shown that the effect of the Online Service Index is higher than the one associated with the Telecommunication Infrastructure Index. Third, when conducting a country-by-country analysis, we conclude that the EGovernment Development Index stimulates economic growth only in four countries out from six. Countries in which economic growth responds positively to e-government are Saudi Arabia, Kuwait, the United Arab Emirates and Bahrain. Among these four countries, the highest impact is found in United Arab Emirates. These results are as expected since United Arab Emirates are the best performer in terms of e-government development among the six GCC countries, as discussed earlier. In Oman and Qatar, the outcomes of e-government are not significant.

As policy recommendations, additional efforts should be made to develop more the human capital in GCC countries, since our estimations show the presence of a negative impact on economic growth. Actions may be particularly related to the adoption of information and telecommunication technologies. Furthermore, Qatar and Oman should improve more their infrastructure and online services because e-government as it nowadays seems to not stimulate economic development in these two countries. Finally, it is also vital to implement suitable laws and regulations to encourage the development e-government by policymakers and the use of e-government by citizens.

\section{REFERENCES}

[1] Grönlund, A., \& Horan, T.A. (2004). Introducing e-Gov: History, definitions, and issues. Communications of the Association for Information Systems 15, pp. 713-729.

[2] U.S. Congress (2002). The E-Government Act of 2002, H. R. 2458-7. Available at: https://www.govinfo.gov/content/pkg/BILLS-107hr2458enr/pdf/BILLS-107hr2458enr.pdf.

[3] World Bank (2002). New-economy sector study: Electronic government and governance-lessons from Argentina. Washington, DC: World Bank.

[4] OECD (2003). The e-Government Imperative. OECD, Paris.

[5] Estevez, E., \& Janowski, T. (2013). Electronic governance for sustainable development - C onceptual framework and state of research. Government Information Quarterly 30 (SUPPL. 1), pp. S94-S109.

[6] García-Sánchez, I.M., Cuadrado-Ballesteros, B., \& Frías-Aceituno, J.V. (2012). Determinants of EGovernment Development: Some Methodological Issues. Journal of Management and Strategy 3, pp. $11-20$.

[7] Ingrams, A., Manoharan, A., Schmidthuber, L. \& Holzer, M. (2018). Stages and determinants of egovernment development: a twelve-year longitudinal study of global cities. International Public Management Journal, doi.org/10.1080/10967494.2018.1467987.

[8] Btoush, M.H., Siddiqi, J. \& Al-adaileh, R. (2009). Barriers and challenges in e-government services: An empirical study In Jordan. Proceeding of 2009 International Conference on Technology Innovation and Industrial Management June 18th-19th Bangkok, Thailand.

[9] Sarrayrih, M.A., \& Sriram, B. (2015). Major challenges in developing a successful e-government: A review on the Sultanate of Oman. Journal of King Saud University - Computer and Information Sciences 27, pp. 230-235. 
[10] Stefanie, A., \& Claudio, C. (2011). The economic and social impacts of e-government. Information Systems Research Group, Department of Informatics, Universitas Friburgensis.

[11] Majeed, M.T., \& Malik, A. (2016). E-government, financial development and economic growth. Pakistan Journal of Applied Economics 26, pp. 107-128.

[12] Srivastava, S.K., \& Panigrahi, P.K. (2016). The impact of e-government and e-business on economic performance: A comparative study of developing and developed countries. Journal of Contemporary Issues in Business and Government 22, pp. 36-50.

[13] Asogwa, B. (2013). Electronic government as a paradigm shift for efficient public services. Library Hi Tech, 31, pp. 141-159.

[14] Gustova, L. (2017). The impact of e-government strategy on economic growth and social development. Master Dissertation, ISCTE Business School.

[15] Thanh, H.T.T, \& Kim, P.S. (2016). The Impact of E-Government on Competitiveness-based Economic Growth in Vietnam. Southeast Asia Journal 26, pp. 59-98.

[16] Von Haldenwang, C. (2004). Electronic Government (E-Government) and Development. European Journal of Development Research 16, pp. 417-432.

[17] Cordella, A., \& Tempini, N. (2011). E-government and bureaucracy: The role of functional simplification in the case of the Venice Municipality. tGov Workshop '11, Brunel University, West London.

[18] Ismail, D., \& Abdelazim, R.M.H. (2016). Adopting eGovernment as a strategic tool for economic development: Insights from Governmental websites in Egypt. EcoMod2016 9383, EcoMod.

[19] Kochanova, A., Hasnain, Z., \& Larson, B. (2017). E-government can be good for business. LSE business review. Retrieved from http://blogs.lse.ac.uk/businessreview/ 2017/10/04/e-government-canbe-good-for-business/.

[20] Majeed, M.T., \& Shah, A. (2018). An Empirical analysis of economic performance of Asian economies: The role of electronic government. Review of Economics and Development Studies 4, pp. 91-102.

[21] Ahmad, E., Aman-Ullah, M., \& Arfeen, M. (2012). Does corruption affect economic growth? Latin American Journal of Economics 49, pp. 277-305.

[22] Hassan, S.A. (2017). Investigating the relationship of e-government, control of corruption, economic prosperity and environmental degradation: An analysis of Asian region. International Journal of Innovation and Economic Development 3, pp. 18-35.

[23] Chaushi, A., Fetai, B. \& Chaushi, B.A. (2016). Economic Impact of E-government Development: Evidence from Panel Data. Management International Conference 2016, Pula, Croatia.

[24] Bahrini, R. \& Qaffas, A.A. (2019). Impact of Information and Communication Technology on Economic Growth: Evidence from Developing Countries. Economies 7, p. 21.

[25] Hodrab, R.M.A. (2016). The impact of information and communication technology (ICT) on economic growth - The case of selected Arab countries. PhD Dissertation, Czech University of Life Sciences Prague, Faculty of Economics and Management.

[26] Department of Economic and Social Affairs (2018). United Nations E-Government Survey 2018. United Nations, New York.

\section{Article history:}

Received 6 February 2020

First revision 4 March 2020

Accepted 1 May 2020

„The author gratefully acknowledges the approval and the support of this research study by the grant no. BA-2018-3-9-F-8042 from the Deanship of Scientific Research at Northern Border University, Arar,K.S.A.,, 